\title{
Jurist-Diction
}

Volume 4 No. 6 November 2021

\section{Regulasi Bagi Pengendara Skuter Listrik dan Otoped Listrik di Indonesia}

\author{
Ramadhan Henrison Hasibuan \\ henrisonhasibuan@gmail.com \\ Universitas Airlangga
}

\author{
How to cite: \\ Ramadhan Henrison \\ Hasibuan'Regulasi Bagi \\ Pengendara Skuter Listrik dan \\ Otoped Listrik di Indonesia' \\ (2021) Vol. 4 No. 6 Jurist- \\ Diction. \\ Histori artikel: \\ Submit 6 April 2021; \\ Diterima 15 Oktober 2021; \\ Diterbitkan 5 November 2021 \\ DOI: \\ 10.20473/jd.v4i6.31852 \\ p-ISSN: $2721-8392$ \\ e-ISSN: $2655-8297$ \\ (c) (i) (2)
}

\begin{abstract}
This research aims to determine the existing regulations in Indonesia for motorists and the use of electric scooters on the road. At the beginning of its appearance, there were no clear regulations regulating provisions for electric scooters so that users can ride these transportation freely, causing conflicts between electric scooters user with pedestrians and other vehicle user. Conflicts that occur between electric scooters user and pedestrians include pedestrians who consider the use of electric scooters on sidewalks and pedestrian bridges to endanger pedestrians, while electric scooters are too slow to be used on the road with other vehicle riders. So that it can be dangerous. This article is hoped to be able to answer the regulations that must be obeyed by electric scooters user when driving on the road. Keywords: Electric Scooter; Conflict; Regulation.
\end{abstract}

\begin{abstract}
Abstrak
Penelitian ini bertujuan untuk mengetahui regulasi yang ada di Indonesia bagi pengendara dan pemakaian kendaraan jenis otoped listrik dan skuter listrik di jalan raya. Pada awal kemunculannya belum ada regulasi yang mengatur secara jelas mengenai ketentuan bagi para pengendara skuter listrik dan otoped listrik sehingga pengguna mengendarai alat trasnportasi tersebut secara bebas hingga menimbulkan konflik antara pengendara skuter listrik dan otoped listrik dengan pejalan kaki dan pengendara kendaraan lainnya. Konflik yang terjadi antara pengendara skuter listrik dan otoped listrik dengan pejalan kaki anatara lain adala pejalan kaki menganggap penggunaan otoped listrik dan skuter listrik di trotoar dan jembatan penyebrangan membahayakan pejalan kaki sedangkan dengan pengendara kendaraan lainnya pengemudi skuter listrik dan otoped listrik terlalu lambat berjalan di jalan raya sehingga dapat membahayakan. Artikel ini diharapkan dapat menjawab regulasi yang harus dipatuhi oleh pengendara skuter listrik dan otoped listrik ketika berkendara di jalan raya.

Kata Kunci: Skuter listrik; Otoped Listrik; Konflik; Regulasi.

Copyright (C) 2021 Ramadhan Henrison Hasibuan
\end{abstract}

\section{Pendahuluan}

Dunia otomotif mengalami perkembangan yang cukup signifikan dalam kurun waktu sepuluh tahun terkahir. Para ahli di industri otomotif mulai merancang kendaraan dengan penggerak motor listrik yang mempunyai daya jelajah cukup 
jauh. Munculnya kendaraan berbasis listrik ini merupakan inovasi yang mendapat sambutan baik dari masyarakat dan mulai menyaingi eksistensi kendaraan konvensional berbahan bakar fosil, tidak lain karena kendaraan berbasis listrik dianggap lebih ramah lingkungan karena tidak memproduksi karbon dioksida dari saluran pembuangan.

Perkembangan industri otomotif berdampak juga kepada semakin banyaknya pilihan moda trasnportasi yang tersedia di masyarakat. Kebutuhan akan sarana transportasi yang praktis yang sesuai dengan gaya hidup masyarakat Indonesia, dimana Indonesia merupakan negara yang sedang berkembang, baik dalam bidang ekonomi dan pembangunan. Oleh karena itu, seiring dengan perkembangan tersebut kebutuhan masyarakat akan sarana transportasi yang praktis dan bisa mendukung pola hidup masyarakat yang juga kian dinamis sangat dibutuhkan, sehingga memicu munculnya suatu inovasi di bidang transportasi roda dua. ${ }^{1}$ Hal tersebut juga merupakan pengaruh dari semakin gencarnya pembangunan infrasturktur yang dilakukan di wilayah negara Republik Indonesia sehingga membuat masyarakat semakin nyaman beraktivitas menggunakan jasa transportasi umum.

Salah satu moda transportasi yang mulai digandrungi oleh masyarakat Indonesia adalah skuter listrik dan otopet listrik, alat tranportasi ini beberapa waktu kebelakang menjadi salah satu alternatif alat tranposrtasi yang cukup populer di beberapa wilayah di Indonesia. Pada awal kemunculannya skuter listrik diperkenalkan oleh suatu perusahaan bernama Migo. Migo mendapat respon yang cukup baik dan sangat digandrungi oleh anak muda karena menjadi alternatif transportasi baru yang bisa digunakan dengan murah dan tanpa syarat yang rumit untuk dapat menyewanya. Setelah kemunculan migo, Grab yang merupakan suatu perusahaan jasa angkutan online pun memperkenalkan layanan GrabWheels yang juga merupakan jasa persewaan skuter listrik, selain meluncurkan GrabWheels yang dapat disewa oleh masyarakat umum, Grab juga mulai menggunakan skuter listrik pada layanannya yang lain yaitu GrabFood.

\footnotetext{
${ }^{1}$ Gusti Ayu Putu Yindri Laksmiwani, I Dewa Made Suartha, 'Legalitas Kendaraan Roda Dua Sebagai Angkutan Umum' (2018) 6 Kertha Semaya.[1].
} 
Pada layanan GrabFood skuter listrik digunakan oleh para pengemudi Grab untuk mengantarkan makanan kepada konsumen.

Inovasi yang cukup baik tersebut pada akhirnya menimbulkan beberapa masalah. Karena status alat tranportasi tersbut belum jelas apakah termasuk dalam kategori sepeda atau sepeda motor maka masih belum jelas pula pengunaan jalur yang harus dilalui oleh pengguna skuter maupun otopet listrik tersebut, apakah bisa menggunakan alat transportasi tersebut di trotoar atau harus mengendarai di jalan raya berbarengan dengan kendaraan bermotor lainnya, karena pada umumnya trotoar hanya dipergunakan bagi pejalan kaki ataupun pengendara sepeda seperti yang terjadi di sepanjang Jalan Jenderal Sudirman. Masalah tersebut menjadi kebingunan bagi para pengendaranya dan pada akhirnya menjadi suatu konflik di jalanan. Apabila pengendara skuter listrik mengemudikan kendaraannya di jalan raya maka akan membahayakan karena kecepatan skuter listrik tidak secepat motor atau mobil bermesin konvensional dan konflik tersebut pun telah merenggut korban jiwa dari pengendara otopet listrik yang tertabrak mobil ketika mengendarai otopet tersebut di jalan raya. Mengendarai skuter atau otopet listrik di trotoar pun menimbulkan konflik dengan pejalan kaki karena kecepatan yang dimiliki oleh kendaraan tersebut dianggap terlalu kencang bila berjalan di atas trotoar dan sudah menimbulkan korban pula dari pejalan kaki yang terserempet oleh pengendara skuter atau otopet listrik.

Masalah selanjutnya adalah standar keamanan bagi para pengendara skuter atau otopet listrik tersebut. Akibat belum jelasnya status alat trasnportasi tersebut maka tidak secara jelas pula mengatur kelengkapan apa saja yang harus dikenakan oleh para pengendaranya. Banyak dijumpai pengendara skuter atau otopet listrik tidak memakai helm saat berkendara di jalan raya padahal sudah disediakan oleh penyedia jasa skuter listrik tersebut.

Tidak jelasnya status kendaraan tersebut pula memunculkan kebingungan terkait lokasi untuk parkir. Bagi pengemudi layanan GrabFood yang memakai skuter listrik sebagai sarana transportasinya ketika harus meninggalkan skuter listrik untuk menuju tempat pembelian makan akan menemui permasalahan apakah 
harus memarkirkan kendaraannya di tempat parkir untuk motor atau sepeda. Tentu apabila memarkirkan kendaraannya di tempat parkir untuk motor tidak akan bisa karena rata-rata penyedia jasa lapangan parkir mensyaratkan Surat Tanda Nomor Kendaraan untuk dapat parkir di tempatnya, sedangkan skuter listrik sampai saat ini belum bisa didaftarkan untuk registrasi STNK. Bila ingin memarkirkan di tempat parkiran untuk sepeda pun ukuran skuter listrik yang digunakan oleh pengemudi GrabFood terlalu besar. Pada akhirnya para pengemudi GrabFood tersebut pun memilih memarkirkan kendaraannya di trotoar atau pun pinggir jalan raya yang pada akhirnya menganggu pejalan kaki dan arus lalu lintas.

\section{Metode Penelitian}

Metode yang digunakan dalam penelitian ini adalah penelitian hukum yang dilakukan dengan cara meneliti bahan-bahan pustaka atau data-data sekunder belaka. Penelitian ini bersifat Yuridis Normatif, oleh karena didasarkan pada metode, sistematika, dan pemikiran tertentu dengan tujuan mempelajari suatu atau beberapa gejala hukum tertentu dan menganalisisnya.

\section{Regulasi Bagi Pengendara Skuter listrik dan Otoped Listrik Berdasarkan Peraturan PerUndang-Undangan}

Belakangan ini, mulai terjadi perubahan kebiasaan dan pola masyarakat Indonesia dalam melakukan perpindahan menggunakan moda transportasi umum dari satu tempat ke tempat lainnya. Dahulu masyarakat mendatangi lokasi moda transportasi tersebut berada seperti halte maupun stasiun dan masyarakat yang harus mengikuti jadwal moda transportasi tersebut. Saat ini hal tersebut disebut sebagai moda transportasi konvensional di mana belum terlalu banyak menggunakan teknologi.

Seiring berjalannya waktu, ilmu pengetahuan semakin berkembang yang pada akhirnya mempengaruhi kemajuan teknologi bertumbuh sangat pesat. Perkembangan teknologi juga membuat pola hidup masyarakat berubah. Kemajuan teknologi tersebut sangat mempengeruhi bidang transportasi, baik mempengaruhi 
dari segi sistem di dalamnya juga alat transportasi yang digunakan. Sisi baik dari perkembangan teknologi adalah menjadikan semua hal lebih efisien.

Dalam segi sistem, perkembangan teknologi yang sangat terasa pada awalnya adalah metode pembayaran. Zaman dahulu metode pembayaran untuk menggunakan transportasi hanya bisa menggunakan uang tunai, saait ini pilihan metode pembayaran menjadi sangat variatif. Konsumen dapat melakukan pembayaran dengan cara transfer, kartu kredit, debit, maupun kartu berlangganan yang disediakan oleh perusahaan penyedia jasa. Bahkan saat ini ada layanan berupa dompet digital (e-wallet) yang memungkinkan masyarakat melakukan transaksi tangpa membawa uang maupun kartu, metode pembayaran seperti inilah yang umum digunakan untuk menyewa skuter listrik seperti GrabWheels. Pengguna dengan mudah memindai barcode yang ada pada skuter listrik lalu saldo yang ada pada e-wallet akan terpotong secara otomatis sehingga skuter listrik dapat digunakan. Hal kedua yang dipengaruhi olehs sistem adalah cara masyarakat memperoleh akses terhadap moda transportasi, pada zaman sekarang masyarakat tinggal memesan transportasi yang diinginkan melalu aplikasi lalu kendaraan tersebut akan menghampiri konsumennya. Bahkan untuk skuter listrik tidak ada pihak dari penyedia jasa yang menunggu pada tiap titik penyewaan untuk melakukan transaksi dengan pelanggan yang ingin menyewa skuter listrik atau otoped listriknya, para pengguna cukup memindai barcode yang ada untuk menggunakan alat transportasi tersebut. Hal seperti itu sangat membantu bagi kedua belah pihak, bagi penyedia jasa mereka tidak perlu mempekerjakan banyak orang untuk dapat mengoperasikan alat tersebut, bagi pengguna mereka pun dengan mudah menemui titik penyewaan di sekitar wilayahnya karena sudah banyak tersedia.

Dalam hal alat transportasi yang digunakan perkembangan teknologi yang sangat pesat juga mempengaruhi pilihan moda transportasi yang digunakan. Zaman dahulu masyrakat hanya mengenal kendaraan tanpa mesin seperti kereta kuda, becak, dan sepeda. Hingga akhirnya masyarakat mulai mengenal mesin konvensional yang digerakkan menggunakan bahan bakar fossil. Setelah cukup lama berada pada era tersebut masyarak mulai menemukan energi baru untuk 
menggerakkan suatu kendaraan yaitu listrik. Penemuan ini dianggap sebagai masa depan alat transportasi bagi generasi yang akan datang. Listrik dianggap jauh lebih ramah lingkungan serta praktis, tidak ada pembakaran minyak pada motor listrik yang menyebabkan tidak adanya karbon dioksida yang diproduksi oleh mesin listrik sehingga dapat memperbaiki kualitas udara dunia yang sudah mulai rusak. Listrik juga dianggap praktis karena sistem kerjanya yang lebih simpel sehingga tidak memerlukan perawatan seperti mesin konvensional. Biaya yang dikeluarkan untuk mengoperasikan alat transportasi berbasis listrik pun sangat murah dibandingakan menggunakan bahan bakar minyak. Alat transportasi pun wujudnya menjadi sangat beragam yang mulanya hanya mobil, motor, dan bis yang umum digunakan sebagai alat transportasi dengan tenaga listrik muncul wujud baru alat transportasi seperti otoped, hoverboard, dan sepeda roda satu (unicycle).

Mulai munculnya bentuk alat transportasi baru membuat regulasi yang ada seakan belum cukup untuk mengatur perkembangan yang terjadi atas masifnya kemajuan teknologi. Undang-Undang transportasi yang lama tidak mengatur alatalat tersebut sebagai salah satu moda transportasi. Padahal mulai marak pengguna alat transportasi tersebut terutama pada kota-kota besar seperti Jakarta, Surabaya, dan Bali. Tidak tercakupnya alat-alat tersebut pada akhirnya berdampak pada regulasi yang harus dipatuhi oleh penggunanya.

Berdasarkan berita yang dilansir CNBC, Grab Indonesia melakukan riset langsung kepada 3.107 pengguna dan juga bukan pengguna GrabWheels pada 28 November $2019 .^{2}$ Riset ini untuk mencari bukti nyata dampak sosial yang dihadirkan oleh moda transportasi ini. Hasil riset tersebut adalah 9 dari 10 masyarakat Jakarta mendukung adanya GrabWheels. Di mana 91\% dari pengguna di Jakarta, 45\% diantaranya mendukung bila disertai dengan peningkatan lainnya. Selanjutnya, masih dalam hasil riset, sebanyak $75 \%$ dari responden setuju bahwa

2 Yuni Astutik, '61\% Pengguna GrabWheels Akui Menghemat Biaya Transportasi' (CNBC Indonesia, 2019) <https://www.cnbcindonesia.com/tech/20191129174227-37-119176/61-pengguna-grabwheels-akui-menghemat-biaya-transportasi> accessed 10 December 2020. 
GrabWheels meningkatkan persepsi mereka tentang kota yang lebih ramah lingkungan, inovatif dan menyenangkan. Hasil lainnya adalah $72 \%$ pengguna GrabWheels akan kembali menggunakan transportasi beremisi karbon bila tidak ada Grabwheels. Selanjutnya 59\% pengguna setuju bahwa mereka akan meninggalkan kendaraan bermotor jika GrabWheels lebih banyak tersedia di Jakarta. " $52 \%$ pengguna setuju bahwa GrabWheels telah mengurangi ketergantungan mereka terhadap kendaraan bermotor," GrabWheels juga membawa dampak ekonomi secara signifikan bagi pengguna dan mitra penyedia area parkir. Adapun sebagai informasi 28\% atau 858 respon adalah pengguna GrabWheels dan sisanya 72\% atau 2.249 bukan merupakan pengguna. Grab mencatat $61 \%$ pengguna setuju bahwa GrabWheels membantu mengurangi biaya transportasi. $85 \%$ responden juga setuju bahwa GrabWheels menciptakan peluang untuk memperoleh penghasilan tambahan dan $81 \%$ responden setuju bahwa GrabWheels menambah daya tarik usaha sehingga meningkatkan jumlah pengunjung. Adapun hasil survei yang berdampak pada ekonomi ini melibatkan 68 mitra UMKM penyedia parkir GrabWheels. ${ }^{3}$

Pada awal kemunculannya belum ada regulasi yang jelas mengatur mengenai alat transportasi tersebut berikut aturan terkait tata cara penggunannya di jalan raya. Sehingga banyak terjadi konflik atas kemunculan skuter elektrik di jalan raya. Salah satu fenomena yang menjadi perdebatan adalah penggunaan skuter listrik pada arena Car Free Day hal ini bertentangan dengan Pasal 1 angka 8 Peraturang Gubernur Provinsi Daerah Khusus Ibukota Jakarta Nomor 12 Tahun 2016 yang menyebutkan:

\section{Pasal 1 angka 8}

Hari Bebas Kendaraan Bermotor yang selanjutnya disingkat HBKB adalah hari dimana pada suatu periode waktu tertentu kendaraan bermotor (kecuali Bus Trans Jakarta yang menggunakan Bahan Bakar Gas) tidak boleh melintasi kawasan/ruas jalan yang sudah ditetapkan sebagai lokasi pelaksanaan HBKB, dimana pada pelaksanaan HBKB tersebut terdapat 3 (tiga) kegiatan utama yang dilaksanakan yaitu penutupan jalan, pengukuran kualitas udara, dan kegiatan penunjang lainnya. 
Pengguna skuter listrik dan pengguna jalan yang lain akhirnya menjadi korban atas kekosongan hukum yang ada. Akibatnya pada tahun 2019 terjadi insiden yang menewaskan dua orang pengguna GrabWheels. Setelah kejadian tersebut barulah para pemangku kepentingan bereaksi atas keberadaan otoped listrik di Jakarta, amat disayangkan reaksi yang muncul pada awalnya adalah pelarangan terhadap alat transportasi tersebut di jalanan Jakarta.

Pelarangan tersebut amat disayangkan oleh banyak pihak karena otoped listrik dan skuter listrik dianggap menjadi solusi yang sangat baik sebagai transportasi pada first and last mile bagi warga. Hal tersebut tidak terlepas dari belum terjangkaunya semua wilayah yang ada di Jakarta oleh bis, atau angkutan kota sehingga warga memilih alat transportasi tersebut. Minat masyarakat terhadap transportasi umum juga meningkat seiring dengan semakin baiknya moda transportasi umum dan juga tersedianya alat transportasi seperti otoped listrik dan skuter listrik yang efisien dan praktis semakin memudahkan mobilitas warga, salah satu alasannya karena otoped listrik dapat dilipat dan dibawa masuk ke dalam kereta maupun MRT.

Kekosongan hukum tersebut juga membuat aparat yang berwenang baik kepolisian maupun satpol PP bingung untuk menindak para pegguna skuter listrik. Pihak kepolisian akhirnya memutuskan menggunakan Pasal 282 UU No. 22/2009 yang berbunyi “Setiap Pengguna Jalan yang tidak mematuhi perintah yang diberikan oleh petugas Kepolisian Negara Republik Indonesia sebagaimana dimaksud dalam Pasal 104 ayat (3) dipidana dengan pidana kurungan paling lama 1 (satu) bulan atau denda paling banyak Rp250.000,00 (dua ratus lima puluh ribu rupiah). ${ }^{4}$ Dasar hukum yang digunakan menjadi sangat lemah dan tidak menimbulkan efek jera karena tilang hanya bisa dilakukan bila pelanggar tidak mematuhi apa yang dikatakan oleh polisi, bila pelanggar patuh dengan perintah atau imbauan dari polisi maka tidak dapat dikenakan tilang. Sebelum adanya peraturan terkait kendaraan tertentu dengan penggerak motor listrik tertentu polisi mengkalsifikasikan skuter listrik dan otoped listrik sebagai kendaraan bermotor berdasarkan UULLAJ No.

${ }^{4}$ Pasal 282 UU No. 22 Tahun 2009 tentang Lalu Lintas Dan Angkutan Jalan (Lembaran negara Republik Indonesia Tahun 2009 Nomor 96). 
22/2009. Sehingga dalam melakukan penindakan polisi melakukan penyitaan terhadap otoped listrik maupun KTP pengendara. Penilangan yang dilakukan polisi berdasrkan Kartu Tanda Penduduk (KTP) pengguna bertentangan dengan Pasal 32 ayat (1) Peraturan Pemerintah No. 80/2012 tentang Tata Cara Pemeriksaan Kendaraan Bermotor Di Jalan Dan Penindakan Pelangaran Lalu Lintas Dan Angkutan Jalan yang menjelaskan bahwa:

Pasal 32 ayat (1)

Petugas Pemeriksa Kendaraan Bermotor di Jalan dapat melakukan penyitaan atas:

a. Surat Izin Mengemudi;

b. Surat Tanda Nomor Kendaraan Bermotor;

c. surat izin penyelenggaraan angkutan umum;

d. tanda bukti lulus uji;

e. barang muatan; dan/atau

f. Kendaraan Bermotor yang digunakan melakukan pelanggaran.

Penyitaan langsung atas perangkat otoped listrik maupun skuter listrik juga tidak dapat dibenarkan karena Pasal 32 ayat (6) Peraturan Pemerintah No. 80/2012 tentang Tata Cara Pemeriksaan Kendaraan Bermotor Di Jalan Dan Penindakan Pelangaran Lalu Lintas Dan Angkutan Jalan yang menjelaskan bahwa:

Pasal 32 ayat (6)

Penyitaan atas Kendaraan Bermotor sebagaimana dimaksud pada ayat (1) huruf f dilakukan jika:

a. Kendaraan Bermotor tidak dilengkapi dengan Surat Tanda Nomor Kendaraan yang sah pada waktu dilakukan Pemeriksaan Kendaraan Bermotor di Jalan;

b. pengemudi tidak memiliki Surat Izin Mengemudi;

c. terjadi pelanggaran atas persyaratan teknis dan persyaratan laik jalan Kendaraan Bermotor;

d. Kendaraan Bermotor diduga berasal dari hasil tindak pidana atau digunakan untuk melakukan tindak pidana; atau

e. Kendaraan Bermotor terlibat kecelakaan lalu lintas yang mengakibatkan meninggalnya orang atau luka berat.

Sehingga penyitaan terhadap perangkat otoped listrik maupun skuter listrik juga tidak dapat dibenarkan karena penyitaan terhadap kendaraan menjadi opsi terakhir bila pengendara memenuhi salah satu syarat dari Pasal 32 ayat (6) Peraturan Pemerintah No. 80/2012. 
Setelah perdebatan panjang terakit status otoped listrik dan skuter listrik sebagai alat transportasi apakah kedua kendaraan tersebut termasuk dalam kategori kendaraan bermotor dalam UULLAJ No.22/2009 atau tidak sehingga menyebabkan kebingungan aparatur penegak hukum menindak pengguna skuter listrik maupun otoped listrik yang melanggar ketentuan dalam UULLAJ No. 22/2009, Kementerian Perhubungan menerbitkan Peraturan Menteri Perhubungan Republik Indonesia Nomor PM 45 Tahun 2020 Tentang Kendaraan Tertentu Dengan Menggunakan Penggerak Motor Listrik yang memberikan kejelasan dan legalitas atas status skuter listrik dan otoped listrik sebagai alat transportasi.

Setelah keluarnya PM 45 Tahun 2020 maka semakin jelas regulasi yang harus dipatuhi oleh pengendara kendaraan tertentu. Pasal 4 PM 45 Tahun 2020 menyebutkan sebagai berikut:

Pasal 4

(1) Setiap orang yang menggunakan kendaraan tertentu sebagaimana dimaksud dalam Pasal 2 ayat (1) harus memenuhi ketentuan:

a. menggunakan helm;

b. usia pengguna paling rendah 12 (dua belas) tahun;

c. tidak diperbolehkan untuk mengangkut penumpang kecuali Sepeda Listrik yang dilengkapi dengan tempat duduk penumpang;

d. tidak diperbolehkan melakukan modifikasi daya motor yang dapat meningkatkan kecepatan;

e. memahami dan mematuhi tata cara berlalu lintas meliputi:

1. menggunakan kendaraan tertentu secara tertib dengan memperhatikan keselamatan pengguna jalan lain;

2. memberikan prioritas pada pejalan kaki;

3. menjaga jarak aman dari pengguna jalan lain; dan

4. membawa kendaraan tertentu dengan penuh konsentrasi.

(2) Dalam hal pengguna kendaraan tertentu berusia 12 (dua belas) tahun sampai dengan 15 (lima belas) tahun, pengguna kendaraan tertentu harus didampingi oleh orang dewasa.

Bagi pengendara skuter listrik milik pribadi memenuhi persyaratan tersebut tidak lah susah dan mayoritas pengguna otoped listrik dan skuter listrik perorangan merupakan orang dewasa. Masalah timbul pada penggunaan skuter listrik dan otoped listrik sewaaan yang disediakan oleh GrabWheels dan Migo. Masih banyak dijumpai pelanggaran pada pengguna jasa GrabWheels dan Migo. Sebelum 
membahas hal tersebut penulis lebih dulu ingin melihat ketentuan penggunaan lain terkait cakupan area pemakaian dalam pasal 5 PM 45 Tahun 2020 yang meyebutkan:

Pasal 5

(1) Kendaraan tertentu sebagaimana dimaksud dalam Pasal 2 ayat (1) dapat dioperasikan pada:

a. lajur khusus; dan/atau

b. kawasan tertentu.

(2) Lajur khusus sebagaimana dimaksud pada ayat (1) huruf a meliputi:

a. lajur sepeda; atau

b. lajur yang disediakan secara khusus untuk Kendaraan Tertentu dengan Menggunakan Penggerak Motor Listrik.

(3) Kawasan tertentu sebagaimana dimaksud pada ayat (1) huruf b meliputi:

a. pemukiman;

b. jalan yang ditetapkan untuk hari bebas kendaraan bermotor (carfree day);

c. kawasan wisata;

d. area sekitar sarana angkutan umum massal sebagai bagian dari Kendaraan Tertentu dengan Menggunakan Penggerak Motor Listrik yang terintegrasi;

e. area kawasan perkantoran; dan

f. area di luar jalan.

(4) Dalam hal tidak tersedia lajur khusus sebagaimana dimaksud pada ayat (2), kendaraan tertentu dapat dioperasikan di trotoar dengan kapasitas memadai dan memperhatikan keselamatan pejalan kaki.

(5) Kapasitas memadai sebagaimana dimaksud pada ayat (4) harus menampung jumlah pejalan kaki dan kendaraan tertentu.

Kewenangan penetapan lajur khusus dan kawasan tertentu untuk penggunaan skuter listrik ada pada Pemerintah Daerah sebagaimana diatur dala Pasal 7 PM 45 Tahun 2020 yang menyebutkan:

\section{Pasal 7}

Penetapan lajur khusus dan/atau kawasan tertentu yang dapat digunakan untuk Kendaraan Tertentu dengan Menggunakan Penggerak Motor Listrik sebagaimana dimaksud dalam Pasal 2 ditetapkan oleh:

a. gubernur Provinsi DKI Jakarta untuk kendaraan tertentu yang beroperasi di Provinsi DKI Jakarta; dan

b. bupati/wali kota untuk kendaraan tertentu yang beroperasi di wilayah kabupaten atau kota.

Bila berkaca pada Jakarta di mana awal mula maraknya penggunaan skuter listrik dan otoped listrik, Pemerintah Provinsi Daerah Khusus Ibukota Jakarta telah menetapkan jalur sepeda melalui Peraturan Gubernur Nomor 128 Tahun 2019 tentang 
Penyediaan Lajur Sepeda. Peraturan ini dibentuk sebagai turunan dari ketentuan Pasal 16 Peraturan Daerah Nomor 5 Tahun 2014 tentang Transportasi, penyediaan jalan untuk kendaraan tidak bermotor antara lain berupa lajur sepeda..$^{5}$ Jelas dalam pembukaan Peraturan Gubernur ini bertujuan untuk mendorong peralihan gaya hidup masyarakat menuju penggunaan kendaraan yang ramah lingkungan. Teknis penyediaan lajur sepeda serta lokasinya diatur dalam Pasal 1 Pergub 128/2019 yang menyatakan sebagai berikut:

Pasal 1

(1) Penyediaan lajur sepeda dilaksanakan pada badan jalan, terpisah dari kendaraan bermotor dengan dilengkapi marka jalan, rambu lalu lintas, dan perlengkapan jalan lainnya sesuai dengan ketentuan peraturan perundangundangan

(2) Selain pada badan jalan sebagaimana dimaksud pada ayat (1), penyediaan lajur sepeda dapat dilaksanakan pada trotoar dengan tetap mengutamakan keselamatan dan keamanan pejalan kaki sesuai dengan ketentuan peraturan perundang-undangan.

(3) Lajur sepeda sebagaimana dimaksud pada ayat (1) dan ayat (2) berlokasi pada ruas jalan sebagai berikut:
a. J1. Medan Merdeka Selatan;
b. J1. M.H. Thamrin;
c. J1. Imam Bonjol;
d. J1. Pangeran Diponegoro;
e. J1. Salemba Raya;
f. J1. Proklamasi;
g. J1. Penataran;
h. J1. Pramuka;
i. J1. Pemuda;
j. J1. Jenderal Sudirman;
k. Ji. Sisingamangaraja;
1. J1. Panglima Polim;
m. J1. RS. Fatmawati Raya;
n. J1. Tomang Raya;
o. J1. Kyai Caringin;
p. Jl. Cideng Timur;
q. Jl. Cideng Barat;
r. Jl. Kebon Sirih;
s. J1. Fachrudin;

${ }^{5}$ Peraturan Gubernur Daerah Khusus Ibukota Jakarta Nomor 128 Tahun 2019 tentang Penyediaan Lajur Sepeda 

t. Jl. Matraman Raya;
u. J1. Jatinegara Barat; dan
v. J1. Jatinegara Timur.

Terkait kawasan tertentu yang diatur dalam Pasal 5 ayat (3) salah satunya adalah jalan yang ditetapkan untuk hari bebas kendaraan bermotor (car free day). Jakarta telah menetapkan lokasi pelaksanaan hari bebas kendaraan bermotor melalui Keputusan Gubernur Provinsi Daerah Khusus Ibukota Jakarta Nomor 545 Tahun 2016 tentang Penetapan Lokasi Dan Jadwal Pelaksanaan Hari Bebas Kendaraan Bermotor. Dalam lampirannya menyatakan sebagai berikut:

\begin{tabular}{ll}
\hline Wilayah & Lokasi Hari Bebas Kendaraan Bermotor \\
\hline Provinsi & Jl. Jend. Sudirman-Jl. MH. Thamrin (Patung Pemuda Membangun s.d \\
DKI Jakarta & Bundaran Patung Kuda/patung Arjuna \\
\hline Jakarta Selatan & Jl. Sisingamangaraja \\
& (Tugu selamat datang s.d Jl. Trunojoyo-Jl. Kyai Maja (CSW) \\
Jakarta Barat & $\begin{array}{l}\text { Kawasan Kota Tua Tamansari } \\
\text { (Jl. Kali Besar Utara-Jl. Kali Besar Timur-Jl. Kali Besar Barat-Jl. Kopi- }\end{array}$ \\
& Jl. Kali Besar Timur 2- sebagian Jl. Kali Besar Timur 3-Jl. Kali Besar \\
& Timur 4-Jl. Kali Besar Timur 5-Jl. Pos Kota) \\
Jakarta Pusat & Jl. Suryo Pranoto \\
(Persimpangan JL. Harmoni s.d Persimpangan RSUD Tarakan) & Jl. Boulevard Raya \\
Jakarta Utara & (Bunderan La Piaza-Jl. Perintis) \\
Jakarta Timur & $\begin{array}{l}\text { Persimpangan Arion (Jl. Pemuda-Jl. Velodrome) s.d Persimpangan Jl. } \\
\text { Pemuda-Jl. Bekasi Raya }\end{array}$ \\
\hline
\end{tabular}

Selain DKI Jakarta kota yang mengatur terkait penyelenggaraan serta lokasi car free day adalah Kota Bandung. Melalui Keputusan Walikota Bandung Nomor 551/Kep.1017-Dishub/2015 tentang Penyelenggaraan Car Free Day Di Kota Bandung. Dalam lampirannya ditentukan lokasi car free day di Bandung sebagai berikut:

\begin{tabular}{ll}
\hline No. & Kawasan Car Free Day \\
\hline 1. & $\begin{array}{l}\text { Jl. Ir. H. Djuanda } \\
\text { (Simpang Dayang Sumbi-Simpang Cikapayang) }\end{array}$ \\
2. & $\begin{array}{l}\text { Jl. Asia Afrika } \\
\text { (Simpang Tamblong-Simpang Alung-alun Timur) }\end{array}$ \\
3. & $\begin{array}{l}\text { Jalan Buah Batu } \\
\text { (Simpang Pelajar Pejuang-Simpang KH. Ahmad Dahlan) }\end{array}$ \\
\hline
\end{tabular}


Tidak ada peraturan mengenai lajur sepeda khusus yang disediakan oleh Pemerintah Kota Bandung seperti halnya yang ada di Jakarta. Meski dalam laman Portalsepeda.com disebutkan ada 6 (enam) ruas jalur sepeda di kota Bandung yaitu: Jalur Asia Afrika, Jalur Balai Kota, Jalur Saparua, Jalur Dago, Jalur Buah Batu, dan Jalur Dipatiukur.

Bila melihat layanan GrabWheels pada aplikasi Grab, khususnya di daerah Jakarta dan sekitarnya di mana penulis tinggal. Terpantau pada aplikasi tersebut GrabWheels tidak bisa dipakai bahkan tidak tersedia di semua wilayah DKI Jakarta. Layanan GrabWheels di Jakarta Selatan hingga Jakarta Pusat hanya tersedia di wilayah Mayestik, Panglima Polim, Barito, Senopati, Blok M, Sudirman, Senayan, Kuningan, Menteng, Monas, dan Cikini. Di luar daerah tersebut masih tersebar di beberapa titik lain seperti di area Rumah Sakit Mitra Keluarga Kemayoran, area Ancol, area Tanjung duren hingga Grogol, dan area Kelapa Gading. GrabWheels juga tersedia di beberapa wilayah Provinsi Banten, yaitu area Bintaro sektor 1 hingga 9 di mana tersedia lajur sepeda di daerah tersebut, area BSD City, dan area Karawaci. Sedangkan di Bandung pada aplikasi Grab terpantau layanan Grab dapat dipakai di semua wilayah Kota Bandung. Pada area-area yang penulis sebutkan di atas Grab menyebut area tersebut sebagai Riding Zone, di luar area tersebut Grab menyebutnya sebagai No-riding zone, tidak ada skuter listrik GrabWheels tersedia pada area tersebut dan pengguna tidak diperbolehkan mengendarai GrabWheels, apabila memasuki area tersebut Grab mengharuskan penggunanya mendorong skuter listrik hingga kembali pada Riding Zone. Grab telah melengkapi perangkat skuter elektrik mereka dengan sensor yang dapat mengontrol apabila pengguna keluar dari Riding Zone skuter akan otomatis berjalan lebih lambat.

Untuk layanan GrabFood di wilayah DKI Jakarta maupun Banten juga terpantau hanya tersedia pada area-area yang sudah penulis sebutkan pada Riding Zone di atas. Pengguna GrabFood menggunakan jenis alat transportasi berupa skuter listrik, berbeda dengan GrabWheels yang menggunakan otoped listrik

Sedangkan untuk layanan Migo Ebike yang juga menggunakan skuter listrik sebagai armadanya, pada aplikasi penulis tidak menemukan adanya area yang 
dilarang untuk dilalui seperti pada layanan GrabWheels, namun terpantau banyak sekali stasiun penyewaan yang tutup dan tidak ada skuter yang dapat disewa sehingga penulis tidak bisa melakukan uji lapangan terhadap layanan Migo Ebike tersebut, bahkan aplikasi acap kali tertutup dengan sendirinya ketika dipakai. Berdasarkan informasi yang diperoleh dari Instagram Migo, layanan Migo sebenarnya tersedia juga di Bandung. Grab dan Migo mempunyai kewajiban untuk para pengguna layananannya sebagaimana yang tertuang dalam Pasal 8 PM 45 Tahun 2020 yang menyebutkan sebagai berikut:

\section{Pasal 8}

Dalam hal Kendaraan Tertentu dengan Menggunakan Penggerak Motor Listrik sebagaimana dimaksud dalam Pasal 2 disewakan, orang/badan yang menyewakan harus:

a. menyediakan tempat penyewaan di luar jalan dan trotoar;

b. memastikan keselamatan pengguna kendaraan tertentu dan pengguna jalan lain; dan

c. mengendalikan kendaraan tertentu sesuai dengan wilayah operasi dan jarak yang ditentukan.

Berdasarkan peraturan dalam Ketentuan Layanan Grab Indonesia Poin 3.1.1 untuk menggunakan layanan Grab setidaknya seseorang harus sudah cakap hukum dan setidaknya berusia dua puluh satu (21) tahun. Namun untuk layanan GrabWheels, Grab dalam lamannya mengatur minimal usia pengguna GrabWheels adalah delapan belas (18) tahun. Dalam Poin 3.3.1 Ketentuan Layanan Grab Indonesia mengizinkan penggunaan untuk orang lain sekurang-kurangnya dua belas (tahun) selama dalam pengawasan dan tanggung jawab tetap pada pemilik akun. Sedangkan untuk Migo dalam ketentuan yang ada dalam lamannya mensyaratkan minimal umur pengguna adalah tujuh belas (17) tahun. Kedua Ketentuan Layanan Grab dan Migo sudah sudah sesuai dengan Peraturan Menteri Perhubungan Nomor PM 45 Tahun 2020.

Terkait penggunaan helm sebenarnya pihak Grab dalam Poin 5.6.10. Aturan Layanan GrabWheels sudah mensyaratkan pengguna mengenakan perlangkapan keselamatan ketika mengendarai GrabWheels dan pihak Grab pun melarang penggunaan otoped listrik bila tidak memenuhi persyaratan tersebut. Namun berdasarkan pengamatan yang penulis lakukan pada perilaku penggunaan 
GrabWheels di Bintaro tidak semua stasiun penyewaan GrabWheels menyediakan helm sehingga pengguna harus membawa helm sendiri, namun banyak dijumpai pengguna yang tidak mengenakan helm ketika berkendara dengan otoped listrik milik GrabWheels. Hal tersebut harus menjadi perhatian pihak Grab, karena tidak ada penjaga pada tiap stasiun penyewaan yang disediakan oleh Grab sehingga penyewa bebas menggunakan otoped listrik tanpa memenuhi persyaratan keamanan yang ditentukan. Beberapa pengguna otoped listrik yang penulis temu juga mengeluhkan tidak tersedianya helm pada semua stasiun penyewaan GrabWheels, tidak adanya penjaga bisa menjadi penyebab hilangnya helm yang sebenarnya diperuntukan bagi penyewa GrabWheels sehingga hal tersebut merugikan pengguna lainnya. Dalam Poin 5.7.8 Grab juga melarang pengguna menggunakan GrabWheels secara berboncengan, hal ini selaras dengan yang diatur dalam Pasal 4 ayat (1) PM 45/2020. Terkait batas kecepatan maksimal otped listrik milik GrabWheels belum sesuai dengan ketentuan yang ditetapkan dalam PM 45/2020 karena otoped listrik masih bisa dipacu hingga kecepatan $15 \mathrm{~km} /$ jam, meskipun kecepatan tersebut sudah dikurangi dari yang seharusnya dapat nerjalan hingga $25 \mathrm{~km} /$ jam sedangkan ketentuan dalam PM45/2020 membatasi kecepatan otoped listrik hanya $6 \mathrm{~km} / \mathrm{jam}$. Stasiun penyewaan sekaligus tempat parkir yang disediakan oleh pihak Grab juga sudah memenuhi ketentuan dalam Pasal 8 PM 45/2020 yang berada di luar badan jalan dan trotoar.

Penulis sempat melakukan wawancara kepada dua pengguna layanan GrabWheels lainnya ketika sedang melakukan pengamatan lapangan terhadap layanan GrabWheels di daerah Bintaro. Pengguna tersebut mengaku belum mengetahui ada aturan khusus yang mengatur terkait tata cara penggunaan otoped listrik di jalan. Panduan pemakaian cukup rinci dijelaskan melalui speaker yang ada pada perangkat GrabWheels tersebut. Berdasarkan pengalaman kedua pengguna yang penulis temui mereka berpendapat jalur yang tersedia di wilayah tersebut sudah cukup baik dan memadai, karena lajur sepeda di daerah Bintaro terpisah dari jalan raya dan juga trotoar untuk pejalan kaki sehingga pengguna merasa aman dan nyaman. Namun kedua pengguna tersebut mengeluhkan masalah yang sama terkait 
tidak tersedianya helm pada tiap stasiun sehigga menjadi kurang aman. Mereka juga mengeluhkan ketersediaan stasiun dan tempat parkir yang dirasa masih kurang, hal ini menjadi masalah karena jumlah perangkat yang dapat parkir pada tiap stasiun dibatasi meski terlihat masih cukup untung menampung lebih banyak perangkat. Hal ini dikhawatirkan akan menjadi masalah apabila pengguna yang tidak cukup peduli memarkirkan perangkat GrabWheels di sembarang tempat sehingga merugikan pengguna jalan lain, meskipun sebenarnya pihak Grab sudah menetapkan denda yang lumayan besar yaitu sejumlah Rp300.000 (tiga ratus ribu) bila kedapatan memarkir perangkat GrabWheels di luar tempat yang sudah ditentukan.

Untuk layanan Migo Ebike berdasarkan ketentuan yang penulis dapat dari laman migo-ebike.com menyebutkan minimal usia untuk menggunakan skuter listrik migo adalah 17 (tujuh belas) tahun, harus menggunakan helm, dan tidak boleh berboncengan, tidak boleh digunakan untuk balapan atau kompetisi. Penulis tidak dapat melakukan pengamatan lapangan terhadap layanan Migo Ebike karena tidak tersedianya perangkat dan aplikasi yang kerap kali crash ketika digunakan.

\section{Kesimpulan}

Regulasi bagi pengguna sudah cukup terakomodir dalam Peraturan Menteri Nomor 45 Tahun 2020, namun peraturan turunan terkait lajur khusus dan kawasan tertentu masih sangat minim sehingga wilayah yang dapat dilalui oleh skuter listrik dan otoped listrik masih abu-abu. Sanksi yang belum secara tegas diatur juga menjadi masalah terhadap pengimplementasian peraturan ini, terutama bagi pengendara otoped listrik sewaan. Acap kali terjadi pelanggaran di lapangan.

\section{Daftar Bacaan}

\section{Buku}

Abdulkadir Muhammad, Hukum Pengangkutan Darat, laut dan Udara (Citra Aditya Bakti 1991).

Merye Agung Kusmagi, Selamat Berkendara di Jalan Raya (Raih Asa Sukses 2010). 
Peter Mahmud Marzuki, Penelitian Hukum, Edisi Revisi (Prenanda Media Group, Jakarta 2017).

\section{Jurnal}

Amelia Lola et al., "Respon Kebijakan Terhadap Transportasi Berbasis Aplikasi Di Jakarta" (2016) The Indonesian Institute.

Hutchinson Terry. 'The Doctrinal Method: Incorporating Interdisciplinary Methods in Reforming the Law'. (2015) 3 Erasmus Law Review, doi: 10.5553/ ELR.000055.

Laksmiwani Gusti Ayu Putu Yindri, I Dewa Made Suartha, 'Legalitas Kendaraan Roda Dua Sebagai Angkutan Umum' (2018) 6 Kertha Semaya.

\section{Laman}

Achmad Dwi, 'Catat Nih! Aturan Main Skuter Listrik di Jalan Raya', (detikFinance,2020) < https://finance.detik.com/berita-ekonomi-bisnis/d5154433/catat-nih-aturan-main-skuter-listrik-di-jalan-raya/2> diakses 17 Desember 2020

detikNews, "Dilema Skuter Listrik: Dilarang di Jalan Raya, Ditolak di Trotoar", news.detik.com, 15 November 2019, h. 1, diakses 7 September 2020.

Joshua Chen, 'E-Scooters Are the Hot Roads and Harleys of Singaporean Youth' (Vice.com,2019) <https://www.vice.com/en/article/pa7mng/escooters-hotrods-harleys-singapore-pmd-lta-youth> diakses 15 Desember 2020

Lova, Cynthia, “Sewa GrabWheels Dini Hari, Dua Pengguna Skuter Listrik Tewas Ditabrak Mobil", https://megapolitan.kompas.com/, 13 November 2019, h. 1, diakses pada 7 September 2020.

Luke Blazejewski, 'What you need to know about new e-scooter lesiglation', (independent.co.uk,2020) <https://www.independent.co.uk/life-style/escooter-electric-legal-renting-rules-law-a9609761.html $>$ diakses 20 Desember 2020.

\section{Peraturan Perundang-undangan}

Undang-Undang Dasar Negara Republik Indonesia Tahun 1945.

Undang-Undang Nomor 22 Tahun 2009 tentang Lalu Lintas Dan Angkutan Jalan, (Lembaran Negara Republik Indonesia Indonesia Tahun 2009 Nomor 96, Tambahan Lembar Negara Nomor 5025). 
Peraturan Pemerintah Nomor 34 Tahun 2006 tentang Jalan (Lembaran negara Republik Indonesia Tahun 2006 Nomor 86, Tambahan Lembaran Negara Republik Indonesia Nomor 4655).

Peraturan Pemerintah Nomor 55 Tahun 2012 tentang Kendaraan (Lembaran Negara Republik Indonesia Tahun 2012 Nomor 120, Tambahan Lembaran Negara Republik Indonesia Nomor 5317).

Peraturan Presiden Nomor 55 Tahun 2019 tentang Percepatan Program Kendaraan Bermotor Listrik Berbasis Baterai (Battery Electric vehicle) Untuk Transportasi Jalan, (Lembaran Negara Republik Indonesia Tahun 2019 Nomor 147, Tambahan Lembar Negara Nomor 6373).

Peraturan Menteri Perhubungan Nomor PM 33 Tahun 2018 tentang Pengujian Tipe Kendaraan Bermotor, (Berita Negara Republik Indonesia Tahun 2018 Nomor 547).

Peraturan Menteri Perhubungan Nomor PM 45 Tahun 2020 tentang Kendaraan Tertentu Dengan Penggerak Motor Listrik, (Berita Negara Republik indonesia Tahun 2020 Nomor 654). 
2442 Ramadhan Henrison: Regulasi bagi Pengendara...

--halaman ini sengaja dibiarkan kosong-- 